\title{
根管充填材による組織反応に対する キモプシンの効果
}

\author{
九州歯科大学口腔病理学教室 (指導 上野正康教授)
}

北 村 勝 也・刍 山 嘉 光・大 木 茂 樹
秋 満 綱 幸・清 永 大三郎

緒言

近年、抗炎症效果を目的として、加水分解醭素を全 身的に投与するといら試みが、臨床的に広く応用され、 いわゆる 酵素療法“として脚光を浴びるようになっ

た。本研究に於て用いたキモプシンは、このような 目的で用いられるものの代表的なものであって、抗炎 症作用のほか、腫脹又は血腫の治療および予防、咯痰 喀出不全の治療などにも優れた效果をあげると云われ ている酵素製凨である。

現在、わたしたちは、各種の根管充填材の諸性唄を いろいろの方向から比較研究している。この一連の研 究の一つとして、感染根管への応用の予備的実験とし て、根管充填材が正常な結合組織に対して、いかなる 反応をよび起すかをしらべた。実験には白鼠の背部皮 下結合組織を用いて、その部に数種の根管充填材を埋 入し、周囲の組織に扣こる变化を顕微鏡的に検索した。 その結果、個々の根管充埧材に於て程度の美はあるが 実験に用いた全ての根管充埧材が、正常な結合組織に 対して意外に強い刺激性を有していると云う実験結果 を得た。これらの実験結果から、わたしたちは、エー ザイ薬品株式会社より寄贈を受けた、牛の胶臓から抽 出して製剤化され、壞死廈を分解し、浮腫や出血巣の 消铅を促進する効果があるといわれる蛋白分解酵素製 剤キモプシンを投与すれば、根管充填材の周团に生じ る壞死屑や、水腫や、出血巣の形成を小範囲にと心゙め、 かつ、それらの消就を促進し、ひいては周团組織の反 沁性炎症の発展に対して、抑制的効果をむたらすであ ろうと考えて実験を行ったのでその結果を報告する次 第である。

\section{実 験 方 法}

実験動物には、重さ150gr前後の成雄白鼠を選び、 実験に用いた根管充媜材は、直径1.0mm、長さ7.0mmの ガッタパーチャーポイントである。手術にあたって動 物を、エーテル吸入麻酔により麻酔後、動物の背面を 電気バリカンにより広範囲に剃って、頸部よりや」下 方に脊柱を中心として左右対称的に脊柱より䄪 $1.0 \mathrm{~cm}$ の位置に脊柱と平行に、長さ約 $1.0 \mathrm{~cm}$ の皮膚切開を加 えた。切開部より外側の皮下結合組織内に切端を鈍に した探針を用いて、可及的刺激を与古ないようにして ガッタパーチャーポイントを埋入する為の細長い組織 空吵を、ガッタパーチャーポイントの長さより、や」 長めに形成した。その空隙内に、予め消毒用アルコール 内に入れて殺菌して执いた前記大きさのガッタパーチ ヤーポイントを埋入した。次に皮膚切開部を綟糸で縫 合し、ガッタパーチャーポイントの埋入部位を明示す るために、該部外皮の四隅に墨汁を注入し、創部に、 一キュロクロームを塗布して手術を終った。

以上の方法に上り、ガッタパーチャーポイントを埋 入した動物を各群 3 匹づつ次の7群に分けて、手術当 日より 4 日間、大腿部筋肉内にキモブシンの注射を行 った。

第 1 群一対照群 (生食水のみ注射)

第 2 群一キモプシン $0.05 \mathrm{mg} / \mathrm{Kg} / \mathrm{day}$ 投与群

第 3 群一キモプシン $0.2 \mathrm{mg} / \mathrm{Kg} / \mathrm{day}$ 投与群 (人の場合の基準量)

第 4 群一キモプシン $1.0 \mathrm{mg} / \mathrm{Kg} / \mathrm{day}$ 投与群 第 5 群一キモプシン10.0 mg/ $\mathrm{kg} / \mathrm{day}$ 投与群 第 6 群一キモプシン $20.0 \mathrm{mg} / \mathrm{Kg} / \mathrm{day}$ 投与群 
第 7 群一キモプシン $45.6 \mathrm{mg} / \mathrm{Kg} / \mathrm{day}$ 投与群 (八木、松岡が奏験により白成の最大耐薬 量としている)

キモプシンの投与量は上記の如くであるが、注射の 量を一定にして各群の全てに 1 日 1 回、1.5 ccつつ大 腿部筋肉内に注射した。

動物は全て、術後7日目に撲殺して、ガッタパーチ ヤーポイント埋入部を、その周四組織と共に切り出し て、通法によりェロイジン包埋、切片作製の後、人マ トキシリン・エオジン染色を施して鏡見した。

\section{実 験 所 見}

\section{A 第 1 群 （対照群）}

\section{1. 第 1 号白氮}

[左側]一切開創哆開のため、感染が認められたの で所見を除外した。

[右側]一ガッタパーチャーポイントをとりかこん で、リンパ球を主とした中等度の細胞浸潤を有する炎 症性肉芽組織が見られ、更にその周团組織は、軽度の 充血と水腫を示している。

\section{2. 第 2 号白瓦}

[左側]一ガッタパーチャーポイントの周囲にはリ ンパ球を主として 中等度の炎症性細胞浸潤が 認めら れ、その部の組織及びその周囲組織は軽度の炎症性水 腫におちいっている。尚、所々に多核巨細胞が散見さ れる。

[右側]一ガッタパーチャーポイントに直接接する 部の組織は、比較的広範团に壊死に括らいって居り、 この壊死層内には遊出せる白血球や多量の赤血球を含 んでいる。壞死層の周囲の組織には多形核白血球、リ ンパ球、組織球等の細胞の浸潤が激しく、血管の怒脹、 充血が著しい。多核巨細胞が霬々見られる。(附図 1)

\section{3. 第 3 号白鼠}

[左側]一ガッタパーチャーポイントの周囲には、 第 2 号白昆右側に見られた以上に、非常に広範囲に壤 死層の形成が見られる。壊死層内には遊出せる白血球 或はそれらが変性したものが多数証められる。罜死層 の周围の結合組織の反応性炎症が強く、多数の多形核 白血球や、組織球、リンパ球等の浸潤が著明である。 この炎症巣の外周の壊死層からはなれたところでは、 紐胞浸潤が漸次軽度となっているが、そこには豊富な 毛細血管と線維芽細胞が認められる。（附図 2)

[右側]一ガッタパーチャーポイントに接する部の 組䅧は、狭小な籁囲に於て、壊死におちいっている。
壇死層を囲む組織は、リンパ球や組織球よりなる中等 度の細胞浸潤を含さ炎症性肉芽組織で、それらは限局 性に壊死層周囲の一部に限られて居り、更にその外周 には、細胞浸潤の少ない細血管や線維芽細胞に富む肉 芽組織が認められる。

B 第 2 群 (キモプシン0.05 mg/Kg/day 投与群)

1. 第 4 号白鼠

両側ともに切開創陊開のため感染を確認したので、 その所見を省く。

2. 第 5 号白鼠

[左側]一ガッタパーチャーポイントは軽度の細胞 浸潤を伴う線維性結合組織により被包されて居り、第 1群に於てみられたよらなガッタパーチャーポイント に接する組織の壊死や出血巣、浮腫等の所見はみられ ない。

[右側]一ガッ|タパーチャーポイントを囲さ組織に は強度の炎症性細胞の浸潤がみられる。浸潤細胞は主 としてリンパ球さあるが、その他多形核白血球や組織 球を混じている。ガッタパーチャーポイントに直接接 する組織の一部には壞死に怙らいれるところもある。 外周の組織には輅度の水腫がある。

3. 第 6 号白臼

[左側]一ガッタパーチャーポイントに接して、僅 かに壊死層の形成が見られる。ガッタパーチャーポイ ントの周囲の組織は、全般的に主としてリンパ球より なる中等度の炎病性細胞浸潤を示して居り、その外周 の組織は炎症性水腫に括らいっている。

[右側]一ガッタパーチャーポイントの周囲には軽 度の懐死啬形成か見られ、その周囲組織には、リンパ 球、多形核白血球、組織球等よりなる強度の細胞浸潤 がある。この炎症巣の中には、時々小出血巣が散見さ れ、又、周囲の組織は軽度の浮腫に和らいっている。 尚、所々に多核目細胞が散見される。(附図 3)

C 第 3 群 (キモプシン0.2 $\mathrm{mg} / \mathrm{Kg} / \mathrm{day}$ 投与群)

1. 第7号白鼠

[左側]一ガッタパーチャーポイントの周囲の組織 は、全面にわたっ大、狭小の範囲に壊死層の形成が見ら れる。壊死層の外周の組織には、リンパ球、組織球を 主とした中等度の細胞浸潤があり、この炎症栄の外周 には、線維芽細胞も豊富にみられる。全般的に、この 炎症巣の附近の組織は水腫状を呈している。尚、本例 に於ても、炎症巣内に多核巨細胞が散見される。（附 図 4) 
[右側]一ガッタパーチャーポイントの周囲には、 軽度に壊死層の形成があり、その外周には、リンパ球 多形核白血球、組織球、線維芽細胞等の細胞浸潤が中 等度に見られる。それらの周囲の組織は軽度の水腫に 招ちいっている。

\section{2. 第 8 号白鼠}

[左側]一中等度の細胞浸潤を示寸炎症性肉芽組織 がガッタパーチャーポイントの周囲を囲んで居り、壊 死層や出血巣はみられない。浸潤せる細胞は、殆んど がリンハ球である。

[右側]一ガッタパーチャーポイントの周囲には、 主にリンパ球よりなる軽度の炎症性細胞の浸潤がみら れるが、壊死層、出血巣、水腫等の所見は見られな い。

\section{3. 第 9 号白鼠}

[左側]一ガッタパーチャーポイントの埋入部が浅 く、ガッタパーチャーポイントが露出していたため、 本例の所見は省略する。

[右側]一ガッタパーチャーポイントの周囲には、 リンパ球を主とした中等度の細胞浸潤がみられ、僅か 飞壊死属が認められるが、水腫や出血巣は著明でな W。

\section{D 第 4 群 (キモプシン $1.0 \mathrm{mg} / \mathrm{Kg} / \mathrm{day}$ 投与群)}

\section{1. 第10号白閔}

〔左側]一ガッタパーチャーポイントの周囲組織の 壊死や、水腫や、或いは出血巣等は見られないが、中 等度の細胞浸潤がある。

〔右側〕一左側と同㥞ガッタパーチャーポイントの 周团組織に、中等度の細胞浸潤を示す。炎症巣内の血 管の桩張充血が左側よりも激しく、巨細胞が多く見ら れる。（附図 5)

\section{2. 第11号白瓦}

[左側]一ガッタパーチャーポイントの周团組織に は限局性にリンパ球、組織球を主とした中等度の細胞 浸潤が見られ、その中には多核巨細胞を混じている。 炎症栄或はその周围組織の血管は拡張、充血し、又、 それらの部は軽度の炎症性水腫に和ちいっている。

〔右側〕一ガッタパーチャーポイントの周囲組織に は、リンパ球、多形核白血球、組織球等の炎症性細胞 の浸潤が源蔓性にひろがっている。その部の血管の拡 張、充血が著しく、所々に出血巣が見られる。多核巨 細胞が多く見られ、組織の水腫も著明である。

3. 第12号白瓦
[左側]一ガッタパーチャーポイントの埋入部が浅 く、露出していたので、所見を省略する。

[右側]一ガッタパーチャーポイントの周囲には少 量の壞死組織が見られ、周囲組織には、リンパ球や組 織球等の他に、多数の多核巨細胞を混じた強い細胞浸 潤が見られる。血管の桩張充血も強い。それらの外周 には線維芽細胞や血管芽細胞の增殖が著明である。

E 第 5 群 (キモプシン $10.0 \mathrm{mg} / \mathrm{Kg} / \mathrm{day}$ 投与群)

1. 第13号白鼠

[左側]一ガッタパーチャーポイントの周团組織に は、主にリンパ球、組織球よりなる炎症性細胞の中等 度の浸潤が見られ、や〉督蔓性にひろがっている。

更に周囲組織には、軽度に血管の充血や水腫が見られ る。(附図 6)

[右側]一ガッタパーチャーポイントの周囲には、 限局性に、リンパ球を主とした中等度の細胞浸潤が見 られ、軽度に水腫状を呈している。

2. 第14号白瓦

[左側]一ガッタパーチャーポイントに直接接する 部の一部に、僅かの懐死組織が認められ、又、比較的 大なる出血巣が存在する。それらの周囲には強度の細 胞浸潤が見られ、全般的には、リンパ球の浸潤が多い が、壊死組織の存在する附近では、多数の多形核白血 球の浸潤がみられる。このような細胞浸潤の強い部に 於ては勿論のこと、近接の結合組織に於ても血管の桩 張充血が著しい。

[右側】一ガッタパーチャーポイントが表面に出て 居り、その附近一帯には膿煌の形成が見られ、感染を 蒙った所見であるので、除外する

\section{3. 第15号白鼠}

[左側]一ガッタパーチャーポイントの周囲の組織 は、リンパ球を主とせる軽度の細胞浸潤がみられ、軽 度の水腫に拈ちいっている。

[右側】一ガッタパーチャーポイントの周囲には、 壞死層の形成はないが、かなり強い炎症性細胞の浸潤 がみられる。炎症性細胞の多くはリンパ球であるが、 多核巨細胞も多くみられる。時には、小さな出血栄が 見られ、水腫におらいれるところもある。

$\mathrm{F}$ 第 6 群 (キモプシン $20.0 \mathrm{mg} / \mathrm{Kg} / \mathrm{day}$ 投与群)

1. 第16号白鼠

[左側]一ガッタパーチャーポイントの周囲組織は 一部、壞死に扣らいれる菲薄な一㬝が存在し、その外 周組織には、中等度の細胞浸潤と小出血巣の存在、或 
は资症性水腫の所見がみられる。多核巨細胞がしばし ばみられる。

[右側]一ガッタパーチャーポイントの周团組織に は、主としてリンパ球からなる中等度の細胞浸潤がみ られ、組織球、多核巨細胞を混じている。左側に於て 見られるよらな壞死組織や、出血巣等は存在しない。

\section{2. 第17号白鼠}

[左側]一ガッタパーチャーポイントが主としてリ ンパ球よりなる軽度の細胞浸潤を示す結合組織より被 包されているが、壊死組織、出血巣、炎症性水腫等の 所見はみられない。

[右側]一左側とほ心゙同様な所見を呈し、ガッタパ 一チャーポイント周团の壞死層形成や、出血巣、炎症 性水腫等の所見は見られず、単に軽度の細胞浸潤を伴 なう結合組織によって被包されているが、浸潤せる細 胞の量が僅かに多い。（附図7）

\section{3. 第18号白鼠}

[左側]一ガッタパーチャーポイントの周囲組織に は、リンパ球、組織球、多核巨細胞、線維芽細胞等か らなる軽度の細胞浸潤がみられる。尚、このような細 胞浸潤巣、或はその周囲組織に、軽度の炎症性水腫の 所見がみられる。

[右側]一第17号白鼠左右側に於てみられたと同じ 様に、ガッタパーチャーポイントの周团には、軽度の 細胞浸潤がみられる程度で、その他著変はみられな W。

\section{G 第 7 群 (キモプシン $45.6 \mathrm{mg} / \mathrm{Kg} / \mathrm{day}$ 投与群)}

1. 第19号白鼠

[左側】一ガッタパーチャーポイントはリンパ球を 主とした軽度の細胞浸潤がみられる結合組織により被 われている。文、かなり多数の巨細胞が認められる。

[右側]一ガッタパーチャーポイントは、緻密な線 維性結合組織により被包されて居り、炎症性細胞の浸 潤は極めて軽度である。

\section{2. 第20号白鼠}

[左側]一ガッタパーチャーポイントの周团組織に は、リンパ球を主とした中等度の細胞浸潤がみられ、 線維茅細胞や、毛細血管にとんでいる。又、屢々多核 巨細胞が散見される。細胞浸潤の周囲組織は軽度の水 連に㧍らいっている。

[右側]一ガッタパーヂャーポイントは、ほぶ正常 な結合組織により被包されて居り、血管の周囲に極め て軽微な囲管性細胞漫潤がみられる。

\section{3. 第21号白四}

[左側]一ガッタパーチャーポイントに直接接する 部に限局して、極く小範囲に、主としてリンパ球の浸 潤がみられ、その周囲は緻密な線維性結合組織が囲ん でいる。

[右側]一軽度の細胞浸潤がみられる線維性結合組 織により、ガッタパーチャーポイントが完全に被包さ れている所見がみられるのみで他に著変はない。（附 図 8)

\section{考按}

本研究を行らにあたって、わたしたらは実験動物と して白鼠を選んだ。このことは、わたしたちが、すで に九州歯科学会雑誌19巻3、4号 ニエポキシ樹脂を基材 とした根管充填剤に関する実験的研究（第 2 報）：に 記載しているごとく白鼠が実験に最も手頃な動物であ るといらことのほかに、この種の实験的研究において は、特に術後感染の影響を考虑する必要があるので、 術後感染にかかりにくい動物を使用するのが望ましい、 といら考学のもとで IngleやGriffith (1949) 或はGu ttuso (1963) が =白鼠は、他の多くの動物よりも術後 感染にか〉りにくい。実際にすべての防腐的予防を無 視してる、手術が注意して行われ、動物を乾燥したケ 一ジ中で飼うことに留意すれば、いろんな手術の後 でも感染しないですむ゙と記述している説に従ったる のであり、かつ、わたしたらのさきの奏験に於ても殆 んど全ての実験例に括いて、感染をみずにすんだ経験 によるものである。

わたしたらは、以前に行った実験で、根管充塤材 を白鼠の背部皮下結合組織内に埋入すると、埋入後 7 日目から14日目頃にかけて、最も激しい炎症性細胞浸 潤がみられるといらことを確認している。本実験にお いては、この炎症性細胞浸潤のもっとも激しい時期を 選んで、動物は、全て、術後7日目に撲殺して、各群 の所見を比較観察した。

先つ、キモプシン非投与の生食水のみを注射した対 照群の所見と、キモプシン投与群の所見とを比較する と、対照群に打いては、上述の如く、当然、全ての例 において、強度乃至中等度の炎症性細胞浸潤がみられ るのみか、5 例中 4 例にかなり、広範囲に亘る壊死組 織がみられた。一方、キモプシン投与群に和いては、 人の基準量と同量の $0.2 \mathrm{mg} / \mathrm{Kg} / \mathrm{day}$ 投与群やそれより 以下の少量投与群に於ても、対照群に比して、ガッタ パーチャーポイントの周囲の壊死層の形成が少く、か 
つ、全般的に水腫が弱く、炎症細胞の浸潤も軽度であ る。更に、1.0mg/Kg/day 以上の大量投与群において は、壊死の見られる例は殆んどなく、大多数の例にお いて細胞浸潤も軽度であった。文、キモプシン投与群 全例を通して、炎症性細胞浸潤のみに限定して眺めて みても、全例中強度の細胞浸潤を起しているものは僅 かに 4 例で、大部分が中等度以下の細胞浸潤であって 特に $20.0 \mathrm{mg} / \mathrm{Kg} / \mathrm{day}$ 投与群の如き、非常に大量を投与 した例では、殆んど全ての例において細胞浸潤が軽度 となっている。

こ〉で、本研究の結果に考察を加える前に、これと 関連のあるわたしたちが、さきに報告したエポキシ樹 脂を基材とした根管充填材 $\mathrm{AH}$-26 に関する研究に ついて少しく言及せざるを得ない。この実験では、A H一26の注かに吉田パスター（本学口腔治療学吉田教 授の処方世るもの)、 $\mathrm{N}_{2}$ 、ホモスフラン・トリオジン クパスターを用いて、白鼠の背部皮下結合組織内に埋 入し、それらの根管充填材の周囲に起る变化について 比較研究を行ったのであるが、その結果、 $\mathrm{N}_{2}$ やホモ スフラン・トリオジンクパスターは、A H一26や吉田 パスターに比して、組織に対する刺激性が強いことを 知り、更に非常に興味ある事実を認めた。即ち、根管 充埧材を結合組織中に埋入後、初期には、根管充塓材 の周囲の組織に扎こる変化は、組織の壞死と水腫が主 であり、炎症性細胞の浸潤は軽度で、術後 7 日目以降 になってから強い細胞浸潤を゙扣こしている。この場合 術後1日目から3 日目頃にかけてみられる組織の壞死 と水腫の範囲が、広範团なものほど、7 日目以降に拉 こって来る炎症性細胞の浸潤が激しく、坡死と水腫の 範囲が狭小なほぼ、7 日目以後におこって来る細胞浸 潤が軽度であるといら一定の相関々係を有していた。 このことは、Guttusoが =通常の炎症性細胞は、敏速 に㗜死領域に移動することは出来ないと考光られる゙ と述べていること、ヌ、Menkin (1950) が 強力な 刺激性の組織凝固物を有することは、激しい炎症性反 応の発現の初期の段階であり、それは白血球の集合上 りも先に起る゙といらことを観察していることを裏づ ける所見である。

上に述べた事実、及び Guttusoや Menkinの説よ り本実験の結果を考察するに、本実験では、全ての動 物を術後7日目に撲殺して居り、ガッタパーチャーポ イント埋入後初期の術后 1 日目や術後 3 日目頃の所見 はみなかったが、撲殺時の所見において、炎症性細胞
浸潤が激しく、かつ、未だに壤死組織が広範囲にみら れる例ほど、埋入後初期には、ガッタパーチャーポイ ント周囲の組織が広範团に壊死に和ちいり、かつ、水 腫が激しく、出血巣が多く存在し、反対に、炎症性細 胞の浸潤が軽度の例ほど、埋入後初期の壊死におちい れる組織の範囲が狭く、かつ、反応性水腫も軽度で、 出血巣子僅少であったものであろうといらことが想像 される。

本実験の結果に於て、キモプシンを投与しなかった 対照群では、他のキモプシンを投与した 6 群に比して ガッタパーチャーポイント周团に強い細胞浸潤がみら れた。更に、キモプシンを投与した6 群についてみると キモプシンを少量投与した第 2 群 (キモプシン0.05mg $/ \mathrm{Kg} / \mathrm{day}$ 投与群) や第 3 群 (キモプシン0.2mg/Kg/day 投与群)の例よりむ、キモプシンを大量投与した第 6 群 (キモプシン20.0mg/ $\mathrm{kg} / \mathrm{day}$ 投与群) や第 7 群 (キ モプシン $45.6 \mathrm{mg} / \mathrm{Kg} / \mathrm{day}$ 投与群) の例に於て、一般的 に炎症細胞の浸潤が軽度であるという結果が出ている が、キモプシン投与群に於て、反応性炎症像が軽度で あるということは、キモプシンを投与した例では、ガ ッタパーチャーポイントの周囲に初期におこる变化、 即ち、ガッタパーチャーポイントに直接接する周囲組 織に扣こる壊死、及び、反応性水腫、出血栄の形成等 に対して、キモプシンが、明らかに、積極的抑制効果 をむたらした影響によるものであると考劣られる。一 方、キモプシン投与群の中で、キモプシンを大量投与 した場合が、少量投与した場合よりる、明らかに反応 性炎症像が軽度であった。

キモプシンが、この上うに、ガッタパーチャーポイ ントの周囲に起る反応性炎症の発展に対して抑制的效 果をもたらすことは、キモプシンが、その蛋白分解の 薬理作用に上り畗死屑を分解して炎症の拡大を特さ党 るとともに、リンパ管や血管の压迫をとり、代謝を促 進して、水腫の消祀退を促進し、又、その線維素溶解作 用により、出血巣や凝血の早期消袙乃至排除に積極的 に作用する結果である。このように、キモプシンが、 蛋白或は線維素を溶解することによって、抗炎症効果 をもたらすことは、臨床成績或は基礎的実験的研究に よって証明され、すでに臨床応用がなされているが、 わたしたちのように、根管充填材を研究の対照に選ん で、キモプシンの抗炎症性効果の判定を行ったものは 他に見られない。

わたしたちの研究は、ガッタパーチャーポイントの 
みを対照とした実験であるが、ガッタパーチャーポイ ソトの周囲に抗こる刺激性の炎症に対して、キモプシ ンが抗炎症性効果をるつるのであることを知った。歯 科臨床に於て、根尖部歯周組織には、細菌性炎症病栄 が全くないと思われる症例に於て直接抜䯣後、或は、 間接抜㭪道後に、根管充填を行った後に、根尖歯根膜の 痛みを訴えて来る患者に震々遭遇する。この痛みの原 因の中には、施術の器械的操作の誤りによって、歯根 膜に大きな器械的損傷を加えたがために反応性炎症を 莒起して来るものもあるが、薬物の過剩充媜による根 尖孔外への溢出による、所謂、薬物の刺激よよると思 われるものが比較的多い。このような場合に、疼痛除 去のための適切な治療がなく、臨床的に極めて困難な 問題として、臨床家をわずらわしている。わたしたち の実験的研究の結果により按ずるに、この薬物溢出の ための刺激による疼痛は、溢出せる根管充填材が刺激 性の強い薬剂であればある程、歯根膜組織の壞死や水 腫が広範囲におこり、更に、出血巣が形成されていて 後には強い反応性炎症性細胞の漫潤が括こって来るた めの結果であると解釈される。

そこで、臨床的にこのような薬物の溢出に上る根尖 部歯根膜の炎症性の疼痛をひきおこした場合には、溢 出せる根管充填材の周囲に壞死屑や、水腫や、出血栄 が生じるのを予め最少限度に防止するか、或は速やか に消裉させて、次に抗こる炎症性細胞の浸潤を可及的 軽微にするべき処置が望まれるわけである。このよう な症例に対して、例劣、異った根管充填材の場合でも 薬物溢出に上る刺激性炎症の本態は本質的には全く同 様なものであるから、本実験により、ガッタパーチャ 一ポイントの周囲に抢こる反応性炎症に対して、抗炎 症性効果を発揮した蛋白融解酵素製隹キモプシンを投 与すれば、澄出せる根管充填材の周囲に生じた壊死屑 や水腫や出血巣を速やか除去し、非細菌性の反応性 炎症の軽减乃至消裉を促すことにより、ひいては、疼 痛の除去或は綏和が可能であろうと考学る。

\section{結}

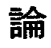

根管充媜材は、正常な結合組織に対して刺激性を有 しており、反応性炎症をひき招こす。わたしたらは、
ガッタパーチャーポイントを選んで、白鼠の背部皮下 結合組織内に埋入し、その結果生じる反応性炎症に対 するキモプシンの抗炎症性効果を判定した。キモプシ ンの投与は、炎症の軽減乃至消能に有効であった。

稿を終るに臨み、終始御想篤なる御指導と御校閲の 労を睗った、恩師上野正康教授に束心より感謝致しま す。

尚、本研究にあたってキモプシンを提供された、エ ーザイ株式会社に謝意を表します。

\section{参考 文 献}

1. 赤崎兼義他 : キモプシンに関する 病理学的研 究、東北医学雑誌、65:480, 1962.

2. Guttu.so J. : Histopathologic study of rat connective tissue responses to endodontic materials, Oral. Surg. Oral. Med. and Oral.

Path. 16:713, 1963.

3. 石川浩一、菅原克彦: 外科分野へのProteaseの 応用と評洒、総合臨床、13:817, 1964

4. 吉田光雄、上野正康他：エポキシ樹脂を基材と した根管充填剂に関する実験的研究（第 2 報)、 九州歯科学会雑誌, $19: 185,1966$.

5. 八木国夫他：キモトリプシンの抗炎症作用、エ 一ザイ株式会社発行

6. $\propto$ 一Chymotrypsin その生化学と治療応用、 エーザイ株式会社編、1961.

7. 外科領域におけるキモプシン療法、エーザイ株 式会社発行、

\section{附 図説明}

1. 第 1 群第 2 号白鼠右側.

2. 第 1 群第 3 号白瓦左側.

3. 第 2 群第 6 号白鼠右側.

4. 第 3 群第 7 号白瓦左側.

5. 第 4 群第10号白鼠右側.

6. 第 5 群第 13 号白鼠左側.

7. 第 6 群第 17 号白鼠右側.

8. 第 7 群第 21 号白鼠右側. 


\title{
AN ANTIINFLAMMATORIC EFFECT OF " CHYMOPSIN " FOR TISSUE RESPONSE RESULTING IN ROOT CANAL FILLING MATERIALS
}

\author{
by \\ Katsuya Kitamura, Yoshimitsu Kameyama, Shigeki $\bar{O} k i$ \\ Tsunayuki Akimitsu, Daizaburo Kiyonaga \\ Department of Oral Pathology, Kyusyu Dental College \\ (Director : Frof. Masayasu Ueno)
}

Root canal filling materials have irritability for living connective tissue, therefore surrounding connective tissues in contact with root canal filling materials is occured inflammatory response.

The purpose of the present paper is to determine the antiinflammatoric result of "Chymopsin "for inflammatory response resulting in root canal filling materials.

In this experiment, guttapercha point was respectively introduced into subcutaneous connective tissue of the back of adult rats, and those animals were injected "Chymopsin" solution postoperatively.

It has been found that injection of "Chymopsin" was effective to the reduction or consumption of inflammation being occured from root canal filling materials. 

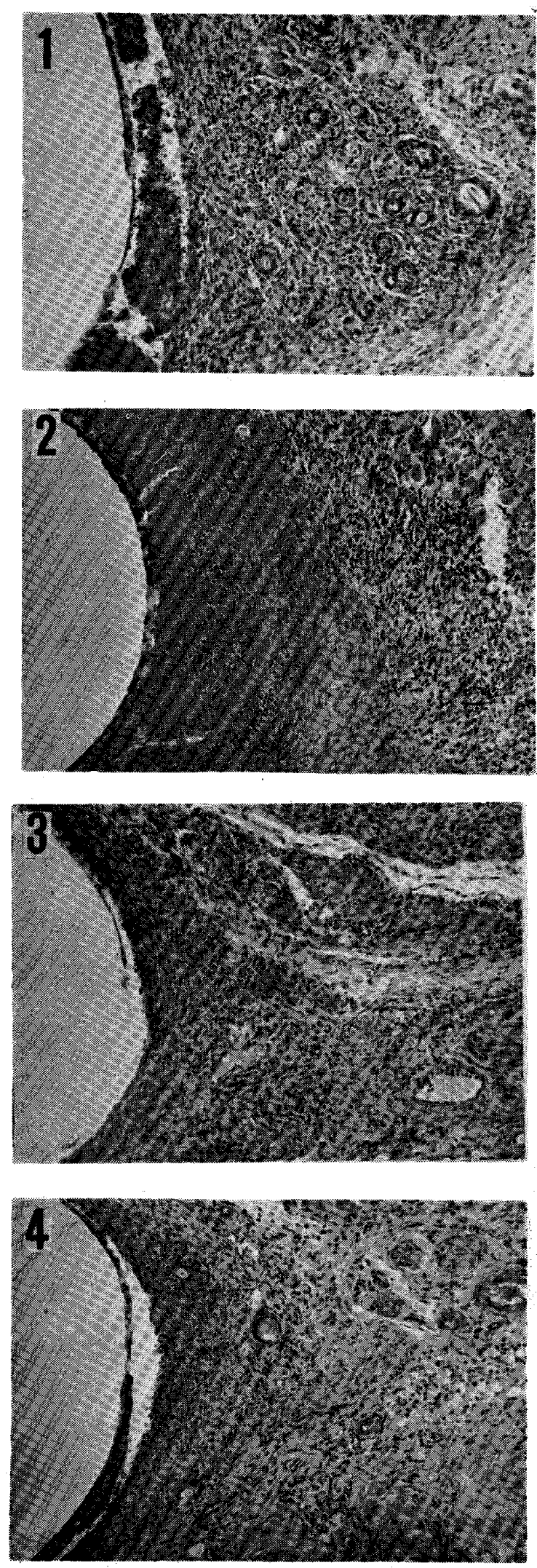
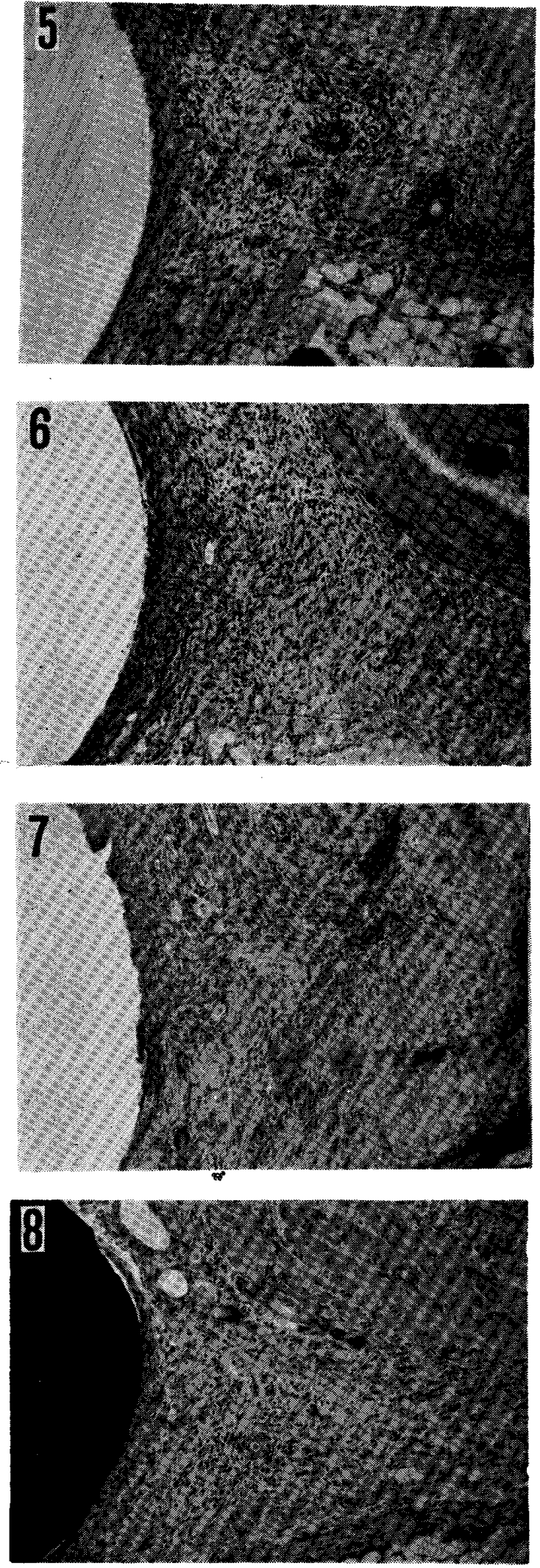